Barbara Jankowska "Coopetition and Internationalization of a Company - the Case of Firms in the Wielkopolska Voivodeship”, Journal of International Studies, Vol. 3, No 1, 2010, pp. 94-102.

\title{
Coopetition and Internationalization of a Company - the Case of Firms in the Wielkopolska Voivodeship
}

\author{
Dr Barbara Jankowska \\ Department of Strategy and Policy of International \\ Competitiveness \\ Poznan University of Economics \\ barbara.jankowska@ue.poznan.pl
}

\begin{abstract}
Cooperation and competition as organizational relationships or interactions between two or more organizations have been traditionally perceived as opposites. Behaviour of enterprises has been changing and one can notice that more and more organizations are involved in these two types of relations simultaneously. This paradoxical phenomenon is named as coopetition. The paper focuses on coopetition and internationalization of a company. Coopetition is a multi-dimensional and multi-faceted phenomenon. In this study, the author attempts to identify the interdependencies between the intensity of coopetition and internationalization of a company. On the basis of literature review the author highlights the theoretical background of the concept of coopetition and conceptualizes the term of coopetition. There are proposed three indicators which can be used in order to assess the intensity of coopetition. The theoretical part of the paper is accompanied by the presentation of the results of empirical research which was conducted among fifty two manufacturing and construction companies involved at least in export as an internationalization strategy and located in Wielkopolska. It is located in the western part of Poland and belongs to the best economically prosperous regions in Poland.
\end{abstract}

Keywords: coopetition, internationalization, enterprise, competitiveness, SME.

Submitted: April, 2010 $1^{\text {st }}$ revision: May, 2010 Accepted: June, 2010

JEL classification: F23, D21.

\section{Introduction}

Cooperation and competition as organizational relationships or interactions between two or more organizations have been traditionally perceived as opposites. Behaviour of enterprises has been changing and one can notice that more and more organizations are involved in these two types of relations simultaneously. This paradoxical phenomenon is named as coopetition. The paper focuses on coopetition and internationalization of a company. Coopetition is a multi-dimensional and multi-faceted phenomenon. In consequence it can take many forms and be located on many levels in the hierarchy of economic systems. The article presented (below) focuses on the coopetition between micro entities, in particular - companies. Some industries, due to the core of a product seem to be predestined to such 
types of interactions.

The problem highlighted in the paper is of great importance for Polish companies which have been trying to win foreign markets and still need strategies that could boost their internationalization. This type of business relations based on mutual trust is of great importance to cope with economic crisis.

The author decided to conduct the research among companies from Wielkopolska because in this region of Poland there were identified three biggest clusters in Poland (looking at the rate of employment, specialization and competitive advantage) (www.clusterobservatory.eu) and coopetition is one of main characteristics of business clusters (Porter 2000, pp. 15-34). Companies in clusters compete and collaborate simultaneously and only then they can benefit from being a cluster participant. Without the phenomenon it is impossible to talk about clusters. Coopetition can appear on the market in different forms. A cluster or industrial district is only one option as Dagnino and Padula (2002) show in their paper. The presence of clusters seems to suggest that in Wielkopolska the companies are involved in this type of business relation and it will be possible to investigate the interdependencies between coopetition and internationalization.

The author tries to identify the interdependencies between the intensity of coopetition and internationalization of a firm. The paper is divided into two parts. The fist part provides a theoretical base of research into the subject of coopetition. The second part focuses on the methodology and results of empirical research. The paper wraps up by short discussion and formulating subjects for future research.

\section{The concept of coopetition}

The notion of a coopetition was used for the first time in 1993 by a founder and CEO of Novell Company - Raymond Noord (Ketchen, Snow, Hoover, 2004, p. 779-804). Afterwards it was adopted by company behaviour researchers and the representatives of the theory of games - Brandenburger and Stuart (1996, p. 5-14) and Nalebuff (Brandenburger, Nalebuff, 1996). The term of a coopetition was to mean a simultaneous competition and cooperation between two or more business partners on the assumption that it leads to repeatable interactions. (Zerbini, Castalado, 2007, p. 941-954). According to Afuah (2000), clients, deliverers, complementators, i.e. producers of goods which are complementary to the basic company offer can become coopetitors. In this understanding a coopetitor is identical with a stakeholder. The set of potential coopetitors has been extended for competitors group by above mentioned Brandenburger and Nalebuff.

We can state that coopetition has an impact on company competitiveness which is intuitively associated with ability to act in an environment with market competitors pressure and achieving better results than rivals on the market. The results of the research reported in the literature show that cooperation with rivals can shape the pool of resources and capabilities of the companies involved in his type of business relations. The resources and capabilities are identified with the competitive potential of the company which is one dimension of competitiveness (Buckley, Pass and Prescott 1998). Another dimension of competitiveness of a firm is its competitive performance - competitive position (Buckley, Pass and Prescott 1988). The subject worth conducting more research are the interdependencies between competitive position of the company on the domestic and foreign markets and the coopetition. The competitive position achieved is a result of the implemented competitive strategy and competitive strategies of the rivals. Competitive position of an enterprise results from the assessment of what the firm offers by the market (particularly by the buyers). The basic and synthetic measures of the competitive position of each enterprise are its share in the market and its financial situation, i.e. profitability of sales of the firm in the 
domestic and in foreign markets as well. (Pierścionek 2007, p. 184). Speaking of international competitiveness is justified when a researched company competes with foreign rivals.

In the literature one can come cross various approaches to the coopetition. The most popular ones are presented in table 1 .

Table 1. Inter-firm coopetition - the nature and theoretical background

\begin{tabular}{|c|c|c|}
\hline The author & $\begin{array}{l}\text { Basic assumption related to the idea of } \\
\text { coopetition }\end{array}$ & Theoretical background \\
\hline $\begin{array}{l}\text { Dagnino, } \\
\text { Padula (2002) }\end{array}$ & $\begin{array}{l}\text { Coopetition }- \text {,an incomplete interest and } \\
\text { goal congruence”. There are four types of co- } \\
\text { opetition: simple dyadic (i.e. alliance - } \\
\text { consortiums in the field of R\&D - only two } \\
\text { partners), complex dyadic ( i.e. alliances in } \\
\text { automobile sectors - many partners, different } \\
\text { fields of cooperation - R\&D, manufacturing } \\
\text { of components), simple network (coopetition } \\
\text { among multiple firms at one level of the value } \\
\text { chain), complex network (i.e. Italian } \\
\text { industrial districts) by the number of } \\
\text { interdependent firms and the level of value } \\
\text { chain. }\end{array}$ & $\begin{array}{l}\text { Transaction cost theory } \\
\text { Resource-based view of } \\
\text { the firm } \\
\text { Industrial economics } \\
\text { Relationships marketing }\end{array}$ \\
\hline $\begin{array}{l}\text { Bengtsson, } \\
\text { Hinttu, Kock } \\
(2003)\end{array}$ & $\begin{array}{l}\text { Coopetition - one of the interorganisational } \\
\text { types of relationships. It is a dyadic complex } \\
\text { relationship that consists both hostility } \\
\text { (conflicting interests) and friendliness } \\
\text { (common interests) at the same time. }\end{array}$ & $\begin{array}{l}\text { Resource-based view of } \\
\text { the firm } \\
\text { Industrial economy } \\
\text { Network approach }\end{array}$ \\
\hline $\begin{array}{l}\text { Fjeldstadt } \quad \text { (et } \\
\text { al 2004) }\end{array}$ & $\begin{array}{l}\text { Coopetition - new form of competition. } \\
\text { Cooperation which occurs in coopetition is } \\
\text { treated as one of the "competitive activities". }\end{array}$ & $\begin{array}{l}\text { Theory of strategic } \\
\text { management }\end{array}$ \\
\hline
\end{tabular}

Source: Based on the literature presented in table 1.

The clue of the coopetition is that enterprises tend to take competitive advantage thanks to specific resources, competence and a defined market position. At the same time they try to integrate their strong points with the resources of competitors. ${ }^{1}$ Coopetition as combination of cooperation and competition is supposed to offer the firm engaged in this type of business relations advantages coming from simultaneous rivalry and cooperation. One of these advantages is the reduction of risk connected with economic activity and becoming involved in new markets. Entering new foreign markets is a sign of internationalization.

Coopetition is, on one hand, mutual making good use of one's competitive potential by companies - coopetitors, on the other hand - permanent severe competitive battle for a cost leadership, market share and inducing technology market changes. Exploitation of such a type of relations, in particular with a competitor, made for a success of the company is a big challenge.

\footnotetext{
${ }^{1}$ More detailed data about the results of coopetition for the international competitiveness of companies can be found in Jankowska (2009, p. 656-665) where the author conducted a literature review in this subject.
} 


\section{Methodology of the study Variables and relationships studied}

The review of a literature related to coopetition provided the author with valuable clues as to the variables which are worth studying in research. Firstly, it is necessary to stress that the focus of research is coopetition. For the sake of empirical research the author used Dagnino and Padula approach to coopetition (2002, p. 15-17) and international competitiveness of a company approach by Pierścionek (2007, p. 184-186). The level of internationalization was measured with three variables: export sales share in total enterprise sales, forms of foreign expansion, number of served foreign markets. ${ }^{2}$ In the table 2 there are presented operationalized variables of the research.

Table 2. Operationalization of research variables

\begin{tabular}{|c|c|}
\hline Variable & Measures and their symbols \\
\hline \multirow{3}{*}{$\begin{array}{l}\text { Intensity of } \\
\text { coopetition (IC) }\end{array}$} & The number of competitors the firm cooperates with (NC) \\
\hline & $\begin{array}{l}\text { Differentiation of cooperative relations with market competitors - } \\
\text { the number of organizational forms of coopetition (NF) (clusters, } \\
\text { networks, strategic alliances, short term agreements, others) }\end{array}$ \\
\hline & $\begin{array}{l}\text { Differentiation of cooperative relations with market competitors - } \\
\text { the number of links in the value chain included in the cooperation } \\
\text { with market competitors (NV) }\end{array}$ \\
\hline \multirow{2}{*}{$\begin{array}{l}\text { International } \\
\text { competitiveness of a } \\
\text { firm (ICF) }\end{array}$} & Relative share in domestic market (SD)/foreign market (SF) \\
\hline & $\begin{array}{l}\text { Profitability of sales on domestic/foreign market compared to key } \\
\text { competitor }(\mathrm{PD}) /(\mathrm{PF})\end{array}$ \\
\hline \multirow{3}{*}{$\begin{array}{l}\text { Internationalization of } \\
\text { the firm (IF) }\end{array}$} & Export sales share in total enterprise sales (EXS) \\
\hline & Forms of foreign expansion (FE) \\
\hline & Number of served foreign markets (NFM) \\
\hline
\end{tabular}

Source: own study

Having in mind potential advantages coming from coopetition, the author formulates the hypothesis, that the increase in coopetition intensity results in the increase of a company internationalization. But to show more real picture it is important to add that the level of internationalization is in many cases determined by the level of international competitiveness of the firm (arrow 3). And international competitiveness is shaped by the pace and scope of internationalization (arrow 4). ${ }^{3}$ The level of internationalization of a firm can be influenced

\footnotetext{
${ }^{2}$ In the literature one can come acorss different approaches to the measurement of internationalization of a firm [Albaum, Strandskov, Geringer, Beamish, da Costa 1989].

${ }^{3}$ Exploratory empirical research on the relation of coopetition with international competitiveness of enterprises was conducted by the author from 10th January to 10th February 2009 among 50 small and medium production and export enterprises from Wielkopolska region. Using Spearman correlation coefficient the author noticed lack of positive relation between the intensity of coopetition and the improvement of its domestic market share and sales profitability on this market. The relation exists, however, in relation to the foreign market. In the case of surveyed companies it can be seen that when the number of competitors a company cooperates with increases, in the managers' opinion there is a growth of foreign market share and sales profitability in foreign markets. A similar increase of the organizational forms of coopetition used by a company and the number of links in value chain results in the increase in share and improvement of sales profitability on foreign markets. The results of exploratory research encouraged formulation of hypothesis that the higher intensity of coopetition results in the increase of a company internationalization (Jankowska 2009, s. 656-665).
} 
directly( arrow 2) and indirectly (arrow 1 and arrow 3) by coopetition. Chart 1 highlights the mentioned relations which were studied in the empirical research.

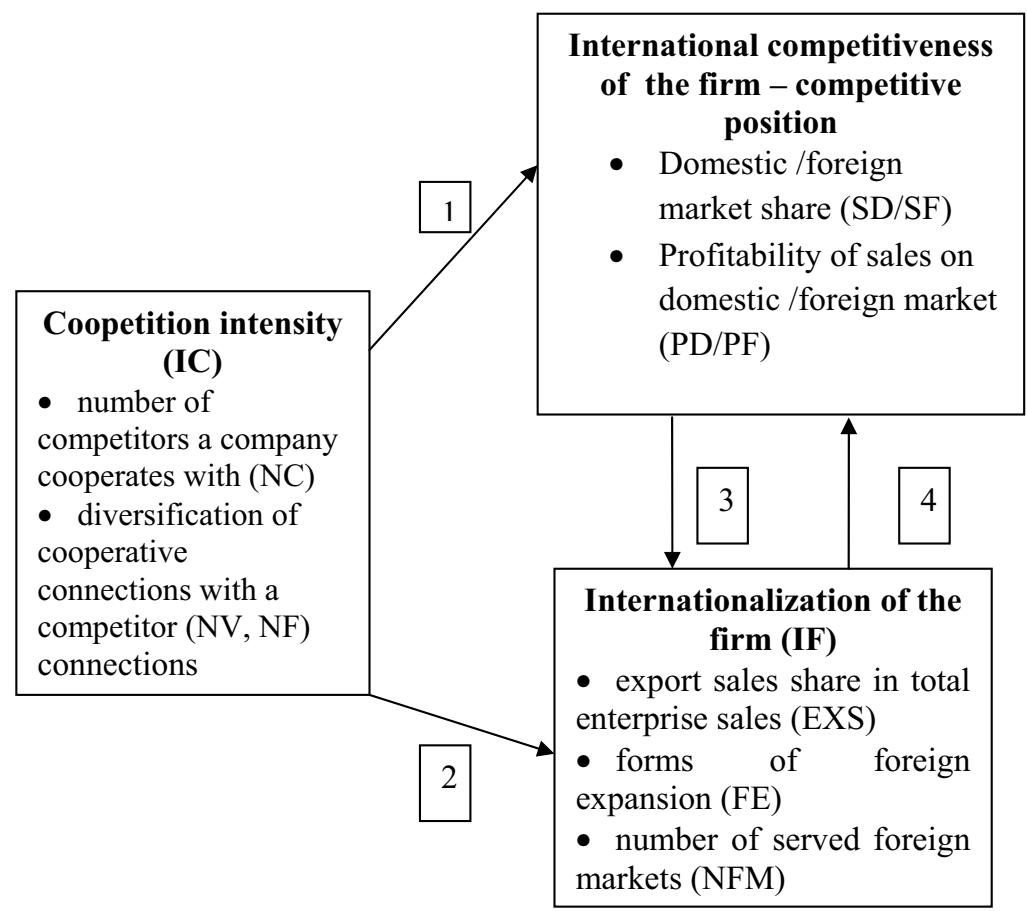

Chart 1.Coopetition against internationalization of the firm

Source: own study

\section{Method of data collection and characteristics of the sample}

The empirical research on the relations of the coopetition and internationalization of the company was led from February 2009 to May 2009. The collected data were processed with a use of STATISTICA 8.0 program. In research, a method of direct interview and in a case of 7 companies - electronic version of questionnaire form was used. After accomplishing the forms the answers were sent by an e-mail and the researcher discussed some answers with the respondents. The questionnaire form was a research device. It contained recruitment, substantial, metric, and evidence parts. In a substantial part there were the questions concerning a characteristics of the coopetition and the relationships between the coopetition and international competitiveness and internationalization of the company. A choice of respondents was made according to 3 recruitment questions of the beginning of the questionnaire form. The questions concerned: employment, a post of a person who potentially will fulfil a form and the fact of cooperating or not cooperating with market rivals. It was agreed that the research does not comprise the micro companies, i.e. the ones employing less that 10 persons. Some companies with more than 249 employees participated in the research. The research was made in production enterprises - D section - Industrial Processing and F section -Construction industry - focusing on the companies providing building services according to the European Classification of Activity. The industries for the research were not chosen randomly. Industrial Processing and Construction industry in Wielkopolska created 
higher gross value added than average for the whole economy in Wielkopolska (Statistical Yearbook for the Republic of Poland 2008, p. 89). The gross value added can be perceived as an indicator of the competitiveness of enterprises from those industries in Wielkopolska.

The condition of being involved in a questionnaire form was also accepting internationalization by a company, at least in a form of export. All of researched companies are placed in Wielkopolska region. The respondents recruited from managing board of medium and high level. For the research of managers' opinions on coopetition and its relations with an international competitiveness an ordinal scale was used. It is a five level scale where: 1 meant definitely not; 2 - rather not; 3 -it's difficult to say; 4 -rather yes; 5 definitely yes. A style and a tone of a scale was synchronized with a style and a tone of specific questions, so that a respondent does not feel a discomfort while answering and marking values on a scale.

The primary assumption of the researcher was to rely on a random selection of the companies chosen for the research sample, at the same time the research was in accordance with the selection criteria presented in the paper. However, serious obstacles that the researcher encountered at the stage of data gathering enforced the alteration of the attitude and the method of non-random unit selection was applied - the convenient selection. The issues of cooperation with market rivals and its implications for enterprises are strictly protected by companies. The convenient way of the sample selection distinctly indicates that the results of the study cannot be generalized. The results can just exemplify the possible interdependencies between coopetition and internationalization of the firm.

The interviews were taken in more than 70 companies, however, the quality of the data gathered in this way caused that only 52 interview questionnaires were used for further analysis. Among those 52 companies there are: 19 which employ from 100 to 249 workers, there are 11 small enterprises with up to 49 employees, 8 entities which employ from 50 to 99 people and 7 companies employing respectively from 250 to 499 workers and more than 499 people. Among the researched enterprises, limited liability companies form the dominant group (24 companies), joint-stock companies (13 enterprises) and one-man companies (9 entities). There were also cases of registered partnerships ( 2 companies), civil companies and co-operatives, also 2 subjects for each category. 12 of the researched companies have a foreign capital share. The sector structure of the researched population is as follows: 42 companies are from section $\mathrm{D}$ - Industrial processing and 10 entities belong to section $\mathrm{F}$ Construction industry.

\section{Results of the research - relationship between coopetition and internationalization}

In the view of descriptive statistics, the opinions of respondents do not allow to unambiguously determine that coopetition is perceived as a factor conducive to internationalization and positively influencing the standards of internationalization. Cooperation with competitors, according to the subjects taking part in the research, contributes to the increase of export share in the total sale of the company (average from categories of responses 3.83), although, on the basis of the opinions of researched entities, one cannot determine how coopetition influences the changes in the portfolio of markets (average from categories of responses 3.29) and undertaking more capital absorbing and risky forms of expansion abroad other than export (evaluation 2.86). When one analyzes the answers of respondents taking into account the size of the companies, we can notice that very big companies - employing more than 499 people as well as companies employing fewer than 50 workers - perceive the importance of cooperation with rivals in the improvement of their export results. The small firms perceive coopetition as a way of acquiring some competencies and resources to be more competitive. From the viewpoint of very big companies, coopetition 
is a strategy used to block other competitors - cooperation with smaller and weaker rivals is the strategy to be stronger in the market. The average from the answer category in sections shows that companies from the processing industry (section D) perceive coopetition as a factor contributing to raising the export engagement to a greater degree than the construction companies (section F), and the opinions are that significant because in the research there were 42 companies from section $\mathrm{D}$ and only 10 from section $\mathrm{F}$.

In Chart 1 it is shown that coopetition may influence internationalization in a direct way (arrow 2) as well as in an indirect way - through the competitive position it takes (arrow 3 ). Trying to recognize if, in case of the researched companies it is really possible to observe the influence, the coefficients of correlation of Spearman ranks, shown in table 3, were measured. The results prove that in case of the researched companies there is no statistically significant relation between the number of coopetitors (NC) and the improvement of the level of company internationalization which was measured by: the increase of export share sales in the total sales of the company (IEXS), the increase in the number of forms of international expansion - the switch to more capital absorbing and risky forms of expansion on foreign markets (IFE), and the increase in the number of foreign markets (IFM). Therefore, it cannot be stated that the increase in the number of coopetitors results in the increase of the level of company internationalization. The number of coopetition forms used (NF) shows statistically significant and positive correlation with the changes in the number of served foreign markets, therefore, the greater number of coopetition forms is positively linked to the increase in the number of served markets. However, the fact in how many fields the company enters coopetition relations (NV) is positively correlated with switching to more risky and capital absorbing forms of internationalization (IFE) and with expansion on new foreign markets (IFM) - the increase in the number of fields included in coopetition is accompanied by positive changes in internationalization valued by the number of forms of expansion and number of foreign markets served by the firm. There is a positive and statistically significant relationship between the increase in international competitiveness of the company identified with competitive position, the increase which is a result of coopetition and the improvement of internationalization. Statistically essential and positive correlation coefficients are observed between the increase in domestic market share (ISD) and foreign market share (ISF), the improvement of sale profitability on the domestic (IPD) and foreign market (IPF) and the increase in export sales share in total sales (IEXS), the number of served foreign markets (IFM) and undertaking of more risky and capital absorbing forms of foreign expansion (IFE).

Table 3. Correlation coefficients of Spearman ranks $(n=52, p=0.05)$

\begin{tabular}{|c|c|c|c|}
\hline & IEXS & IFE & IFM \\
\hline NC & -0.08 & 0.09 & 0.03 \\
\hline NF & -0.01 & 0.12 & $\mathbf{0 . 3 4}$ \\
\hline NV & 0.25 & $\mathbf{0 . 3 7}$ & $\mathbf{0 . 5 7}$ \\
\hline ISD & $\mathbf{0 . 6 0}$ & $\mathbf{0 . 4 9}$ & $\mathbf{0 . 5 3}$ \\
\hline IPD & $\mathbf{0 . 5 9}$ & $\mathbf{0 . 4 6}$ & $\mathbf{0 . 3 9}$ \\
\hline ISF & $\mathbf{0 . 6 8}$ & $\mathbf{0 . 6 1}$ & $\mathbf{0 . 5 7}$ \\
\hline IPF & $\mathbf{0 . 5 7}$ & $\mathbf{0 . 5 7}$ & $\mathbf{0 . 5 5}$ \\
\hline
\end{tabular}

Source: Author's own study

Coefficients of Spearman ranks show that undoubtedly there is an indirect influence of coopetition on internationalization, thus the improvement in the competitive position is accompanied by the implementation of more capital intensive and more advanced forms of 
foreign expansion. To make the existence of this relationship more credible, it is worth mentioning how the respondents commented on the issue of the changes which coopetition causes as far as their international competitive position is concerned. On average the answers approach level 4, which means, that in the case of the researched entities, coopetition brings about the increase in domestic as well as foreign market share (average answers respectively 3.96 and 3.88), what is more it results in the increase in sales profitability on the domestic as well as foreign markets (average answers respectively 3.79 and 3.71)

\section{Discussion and conclusions}

The results of the empirical research carried out by the author allow drawing some conclusions. Direct interviews with companies from two sections of European Classification of Activity, operating in Wielkopolska show that the companies are aware that there exist some cooperative relations with rivals and that those relations are of some importance to supports the hypotheses highlighted in the literature that coopetition is a promising direction in research and the manifestation of transformation in modern management practices (Ketchen, Snow, Hoover 2004).

However, it would be unfounded to claim that the greater intensification of coopetition definitely leads to the increase in the level of internationalization of the company. The results of the research show that the number of competitors the company cooperates with is not actually linked to the increase in the level of internationalization of the company. Therefore, we can draw a basic conclusion that not the quantity of such relations is crucial but their quality is what counts. To evaluate the quality of coopetition relations one should apply different measures, such as, the time span of such relations, frequency, value, diversity and the level of complexity of the projects mutually implemented. The number of coopetition forms also appeared to be poorly linked to the improvement of internationalization of the company. The fact if the company functions in a cluster, business network, whether it is a part of strategic alliance or just a short-term agreement matters only in the range of developing of the market portfolio. The greater the number of the forms used the greater the increase in geographical and spatial dimension of internationalization. However, the measure of intensity of coopetition which shows some links to the measures of internationalization of the company appeared to be the number of links in the chain of value creation. The range of cooperation and thus the number of activity areas included in cooperation with rivals in case of the researched entities is linked to the switch to more capital absorbing and risky forms of internationalization and to expansion on new markets. This result seems to support the hypothesis that not the number of competitors you cooperate with is essential, but the quality of that cooperation. The quality can be associated with the diversity and complexity of coopetitive interactions.

The results presented in the paper give a rather positive image of this type of business relations. But the image obtained is still not clear, it is blurred. One should pay particular attention to the importance of coopetition for the innovation activity of the companies which then results in the strength of competitive potential it possesses. The influence of cooperation with competitors on internationalization may also take place through the changes in innovation of the researched companies. The references seem to imply such a hypothesis. ${ }^{4}$ The following step in the analysis of the data gathered should concentrate on the attempt to identify the relationship between the intensity of coopetition and the changes in innovation of the company which might be operationalized through the following measures - the number of

\footnotetext{
${ }^{4}$ Garcia and Atkin (2005) evaluate on this problem focusing on innovations which result in complete changes in daily consumer functioning and disrupt current routines. Similar problem is discussed by Parker (2000, p. 255260), who argues that cooperation with a rival enables better reaction to customer needs.
} 
new technologies and new marketing strategies implemented or the number of new organizational solutions and products introduced. It could be the direction for future research.

\section{References}

1. Afuah, A. (2000), How much does your coopetitiors' capabilities matter in the face of technological change, Strategic Management Journal, Vol. 21, no 3, Special Issue.

2. Albaum G., Strandskov J., Duerr E., Dowd L. [1989], International Marketing and Export Management, Addison-Wesley, New York.

3. Bengtsson, M., Hinttu, S., Kock, S., (2003), Relationship of Cooperation and Competition between Competitors, Work-in-Progress Paper submitted to the $19^{\text {th }}$ Annual IMP Conference, September 4-6, 2003, Lugano, Switzerland.

4. Brandenburger A.M., Nalebuff B.J., (1996), Co-opetition, New York, Doubleday.

5. Brandenburger, A.M. and Stuart S., (1996), Value-based business strategy, Journal of Economics and Business Strategy, Vol. 5, no 1, 5-14.

6. Dagnino, G.B. and Padula, G., (2002), Coopetition Strategy. A New Kind of Interfirm Dynamics for Value Creation, Paper presented at EURAM - the European Academy of Management, Second Annual Conference - "Innovative Research in Management", Stockholm, 9th-11th May 2002

7. Fjeldstadt, O. D., Becerra, M. and Narayanan, S., (2004). Strategic Action in Network Industries: An Empirical Analysis of the European Mobile Phone Industry, Scandinavian Journal of Management, Vol. 20, no 1-2, 173-196.

8. Garcia, R., Atkin, T., (2005), Co-opetition for the Diffusion of Resistant Innovations: A Case Study in the Global Wine Industry, Institute for Global Innovation Management, Working Paper No: 05-002.

9. Geringer J.M., Beamish P.W., da Costa R.C. [1989], Diversification Strategy and Internationaliztion: Implications for MNE Performance, „Strategic Management Journal”, Vol. 10, no 2, p. 109-119.

10. Greek, P.E., Tull, D.S. and Album, G., (1988), Research for marketing decisions, Englewood Cliffs: Prentice-Hall.

11. Jankowska, B. (2009), Coopetition and International Competitiveness of SME The Case of Companies from One Region in Poland, in: Marketing and entrepreneurship Ankara: Ankara University, p. 656-665.

12. Ketchen, D., Snow, C. and Hoover, V., (2004), Research on competitive dynamics: Recent

13. Pierścionek, Z., (2007), Strategie konkurencji i rozwoju przedsiębiorstwa (Competitive strategies of firms), Warszawa, PWN.

14. Parker, H., (2000), Interfirm Collaboration and the New Product Development Process, Industrial Management \& Data Systems, Vol. 100, no 6, 255-260.

15. Porter, M.E. (2000), 'Location, Competition and Economic Development: Local Clusters in a Global Economy', Economic Development Quarterly, Vol. 14, no. 1, 15-34.

16. Statistical Yearbook for the Republic of Poland 2008, GUS (The Main Statistical Office in Poland), Warszawa.

17. Zerbini, F., Castalado, S., (2007), Stay in or get out the Janus? The maintenance of multiplex relationships between buyers and sellers, Industrial marketing Management, Vol. 36, no 7, 941-954. 